\title{
NEW OR RARE PHILIPPINE REPTILES
}

\author{
By EDWARD H. TAYLOR
}

(From the Section of Ichthyology, Biological Laboratory, Bureau of Science, Manila)

TWO PLATES AND FOUR TEXT FIGURES

In this paper I am describing five new species of snakes and five new lizards from the Philippine Islands. One species is founded on specimens in the Bureau of Science collections, two on specimens in the Santo Tomas Museum of Manila, and the remainder on specimens in my own collections.

The species described and their respective type localities are as follows:

SNAKES

Typhlops luzonensis. Mount Maquiling, Laguna, Luzon.

Typhlops manilæ. "Philippines."

Typhlops longicauda. Bunawan, Agusan, Mindanao.

Typhlops rugosa. Bunawan, Agusan, Mindanao.

Trimeresurus mcgregori. Batan Island, Batan Islands.

LIŻARDS

Lepidodactylus naujanensis. Naujan Lake, Mindoro.

Gekko mindorensis. Pocanil, Mindoro.

Siaphos kempi. Naujan Lake, Mindoro.

Sphenomorphus lednickyi. Aroroy, Masbate.

Sphenomorphus Ilanosi. "Philippines."

SNAKES

Typhlops luzonensis sp. nov.

Type.-No. 109, E. H. Taylor collection; collected on Mount Maquiling, Laguna, Luzon, May 12, 1915, by E. H. Taylor.

Description of type.-Head rather flat, broader than neck, the lower jaw not or scarcely visible in lateral profile; snout rounded, projecting, rather truncate, the end only slightly less deep than head on a level with eyes; portion of rostral visible above much longer and a little wider than the part below, failing to reach the level of the eyes by a minute distance, and minutely less than one-half the width of head; prefrontal forming a suture with rostral little less than one-third its width, larger than frontal, its longest sutures with the supraoculars; frontal, the smallest upper head scale, forming equal sutures with inter- 
parietal and prefrontal; supraocular about the same size as parietal, its lower point barely reaching eye; parietals somewhat narrowed on their lower end; nasal completely divided; nasal suture arises from second labial and after passing nostril reaches rostral in a line horizontal to upper edge of nostril; nasals not in contact behind rostral; preocular reaching above level of eyes, about as broad as ocular, in contact with two labials below; its edge crosses over middle of eye; two postoculars only slightly differentiated from body scales; first labial very small, in contact with anterior nasal only; second labial nearly three time as large as first, touching both nasals and preocular; third labial more than twice as large as second, and a little larger than fourth; lower jaw narrow, about five scales on lower jaw between fourth upper labials; eye a visible black spot, very small, with no pupil evident; about 338 scales from head to vent, 10 subcaudally; tail ending in a small spine.

Color in life.-Above reddish olive brown; below yellowish brown. Each scale with a darker yellowish brown area, giving body a checkered appearance on close examination; rostral, nasal, and labials on underside of snout yellowish white.

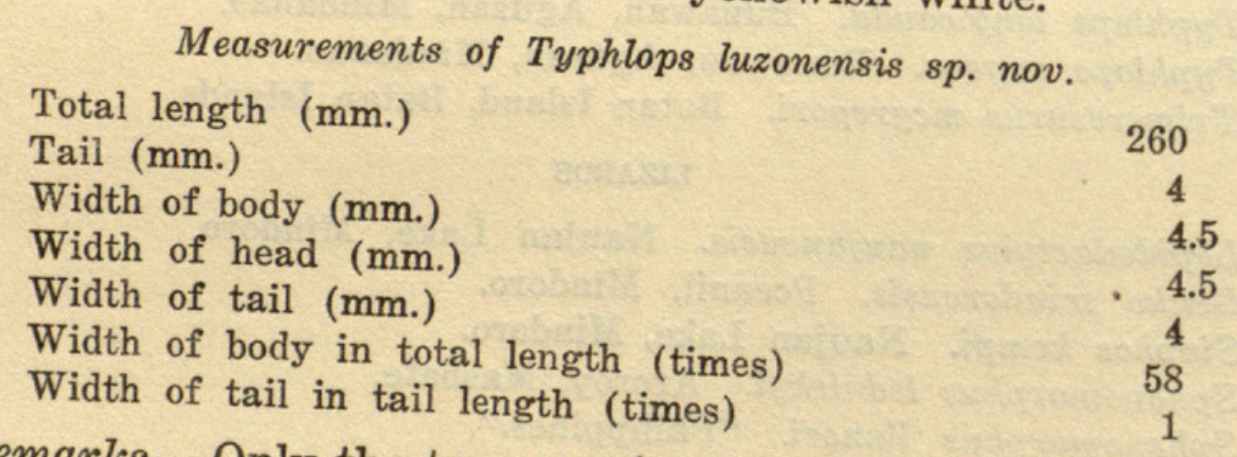

Remarks.-Only the type specimen is known. The species is obviously related to the group of the genus represented by $T$. ruficauda, T. ruber, and T. kraalii, the first two of which are members of the Philippine fauna. From $T$. ruficauda it differs in having four less rows of scales about the body. From $T$. ruber it differs in having the preocular in contact with two labials, the nasal completely divided, and the length greater in propor-
tion to the width of body. (Here the width of body is contained
in the total length 58 times, while in the total length 58 times, while in $T$. ruber, it is contained
36 times.) From $T$. kraalii it differs in having the rostral much
more than one-third the width of the more than one-third the width of the head, and the preocular in contact with two labials; the color is also somewhat different. Typhlops manilæ sp. nov.

Type.-Specimen in Santo Tomas Museum, unnumbered; labeled "Filipinas;" locality and collector unknown. 
Description of type.-Snout rounded in front, projecting; a distinct depression crossing head in region of eyes. Rostral narrowed at a point on snout between nostrils, distinctly longer than wide below; rostral little more than one-third the width of head; nasals not in contact behind rostral; rostral reaching level of eyes; prefrontal rather large, narrowly in contact with frontal; supraoculars large, their lower end not touching eye; frontal slightly smaller than prefrontal, about the same shape; parietals rounding, a little broader than deep, smaller than the supraoculars; interparietal enlarged; nasal not completely divided; the suture issues from the second labial, then makes a backward deflection, widening the anterior part of nasal; preocular narrowed above, reaching above level of eye, but scarcely reaching below level of nostril, abruptly widened below eye, its posterior suture not crossing eye; nasal is much wider than either preocular or ocular; a small subocular scale in contact with second and third labials; preocular touches second labial behind this intercalated scale; ocular widens abruptly on a level with eye; it extends higher than preocular; first labial elongate; second higher and shorter, of nearly the same bulk; third very large, three or four times as large as second, reaching to near the top level of nostril, larger and higher than fourth labial (third labial on one side is fused with subocular); three scales border ocular behind; eyes very small but distinct; nostril comparatively large; lower jaw very narrow, in its middle scarcely two-fifths the width of head. Tail ends in a blunt spine; twelve scales under tail in longitudinal line; snout projecting 2 millimeters.

Color in alcohol.-Reddish brown, darker on posterior twothirds of body; anterior part rather grayish brown. Head distinctly marked with darker and lighter areas; snout yellowish. Below lighter yellowish, each scale with a slightly darker area.

Measurements of Typhlops manilæ sp. nov.

Total length (mm.)

Tail (mm.)

Width of tail ( $\mathrm{mm}$.)

Width of body ( $\mathrm{mm}$.)

Width of head (mm.)

Scale rows
280

Remarks.-This unique specimen was found in the collection of the Santo Tomas University, Manila. The container was labeled "Filipinas" with no indication as to the locality from which it came. This species has no close affinities among other species of the genus in the Philippines as characterized by the 
presence of a subocular. It belongs to the division of the genus of which $T$. ater and $T$. inornatus are members, but differs from all in the very much larger number of scale rows.

Typhlops longicauda sp. nov, Plate I, fig. 1.

Type.-No. R 99, E. H. Taylor collection; collected at Bunawan, Agusan, Mindanao, July 15, 1913, by E. H. Taylor.

Description of type.-Head rather broader than neck, broadly oval in outline; snout with a sharp horizontal cutting edge, moderately projecting, not or but scarcely hooked in profile; rostral not as wide below as above, somewhat narrowed between nostrils, and failing to reach level of eye by more than one-half the depth of prefrontal; the latter wider than deep, larger than frontal, the suture formed with it larger than that with rostral which is only about one-fifth its width; frontal about as wide as deep, equal to the parietals which are about the size of the body scales and scarcely differentiated from them; interparietal somewhat larger than frontal; the supraocular diagonal, the lower point reaching the anterior level of eye, but failing to reach the horizontal level by a distance equal to its distance from nasal; two nasals, the anterior very small, the suture dividing them arises from first interlabial suture; preocular narrower and much shorter than ocular, in contact with two labials below; ocular large, with a slight, rounded prominence over eye; eye and pupil distinct; four postoculars between parietal and fourth labial; four labials, first and second smallest, subequal in size; third more than twice as large as second and about onehalf of fourth; scales in 26 rows; about 430 scales in a longitudinal line to above vent; 40 scales in a row on underside of tail.

Color in life.-Above light yellowish brown, gradually becoming lighter below. Head lighter; laterally a distinct, broadly rectangular, lighter spot, including the eye and reaching the mouth. Each ventral scale has a regular darker brown area.

Total length $(\mathrm{mm}$.

Measurements of Typhlops longicauda sp. nov.

Tail (mm.)

Width of head ( $\mathrm{mm}$.)

Width of body (mm.)

Width of tail $(\mathrm{mm}$.)

Body width in length (times)

Tail width in tail length (times)

340

34.5

5.5

6

4.75

56.6

7.2

Remarks.-This species has a very marked, apparently normal, enlargement of the pelvic region, which suggests a greater de- 
velopment of the pelvic bones or the rudimentary leg bones. The tail in this species is believed to be comparatively longer than in any other of the extremely numerous species of this genus.

The type specimen was obtained from the trunk of a small tree, which was bored full of tunnels by large black ants. It probably feeds on the larvæ of ants. There are eleven specimens in my collection.

Typhlops rugosa sp. nov.

Type.-No. R 97, E. H. Taylor collection; collected at Bunawan, Agusan, Mindanao, July 14, 1913, by E. H. Taylor.

Description of type.-Head rough, the anterior outline broken by depressions between scales along the sutures. Rostral a little longer than wide above, not reaching to level of eyes, more than one-third the width of head; below the enlarged part about as deep as wide, forming a slightly curved hook on snout; rostral dimly granular; prefrontal a little wider and somewhat smaller than frontal, its posterior point reaching a little beyond level of eyes; frontal as broad as long, the distance from oculars equal to distance between nasals, larger than interparietal; supraoculars larger than frontal, wider than deep; parietals much larger than frontal, separated by an interparietal, which is smaller than frontal; parietal not twice as wide as long; nasal with a swollen prominence about and above nostril, which gives the anterior head outline a roughened appearance; nostrils lateroinferior, not visible from above; nasal cleft issues from first labial and barely passes beyond nostril, not wholly dividing the scale; preocular not as wide as, and much shorter than, nasal, in contact with two labials; eyes dim, barely outlined; two postoculars, the inferior largest, in contact with fourth labial; four upper labials, fourth largest, first and second smallest, subequal in size; scales in 26 rows; tail ending in a sharp spine; 479 scales in a dorsal longitudinal line.

Color in life.-Above brownish to golden yellow, slightly lighter beneath. Very little distinction between the two colors as they merge gradually on the sides.

Measurements of Typhlops rugosa sp. nov.

Total length (mm.)

Tail (mm.)

Width of head (mm.)

Width of body (mm.)

Width of tail (mm.) 
Remarks.-Two other specimens besides the type were taken, an adult and a young. These two specimens were forwarded to Dr. Lawrence E. Griffin at the University of Pittsburg. They have not been at hand for comparison. All were taken in masses of fern roots growing in high forest trees. This species has no close affinities among the Philippine species unless $T$. mindanensis be regarded as such. From this it differs in the size of the frontal, which is larger than the prefrontal in $T$. mindanensis. One has two, the other three, labials touching the nasal. In one the head is very rough; in the other, comparatively smooth. Many other differences are obvious on a comparison of the two descriptions. The roughness of the head is not unlike that in $T$. rossii and $T$. reginx, but here the resemblance ceases.

Trimeresurus mcgregori sp. nov. Fig. 1.

Type.-No. 748, Bureau of Science collection; collected on Batan Island, Batanes group (lying between Luzon and Formosa), June 12, 1907, by Richard C. McGregor.
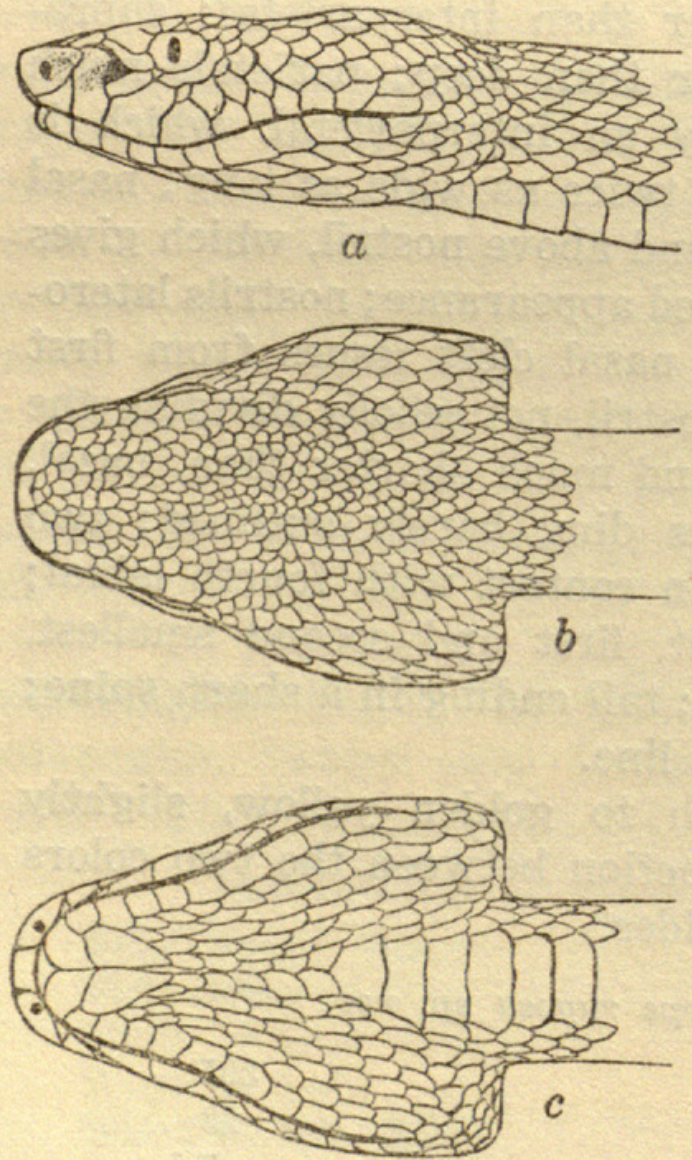

Fra. 1. Trimeresurus megregori sp. nov., from the type, $\times 1$. $a$, head, lateral view; $b$, head, dorsal view; $c$, chin.
Description of type.-Rostral a little wider than high, slightly narrower at top, visible above as a narrow line, bordered behind by a rectangular scale, distinctly enlarged, which separates the two much enlarged supranasals; latter not or barely in contact with rostral, separated from anterior supraocular by three (four on right side) scales; two enlarged supraoculars followed by one or two small scales above eye; nasal single, large, triangular, visible above as a narrow line, the nostril, which is vertically oval, pierced near the lower border; canthus rostralis sharp, formed by the edge of nasal, the narrow elongate loreal following nasal, and superior preocular; facial pit surrounded by second labial, which forms anterior border of pit, and 
middle and lower preoculars, which are much elongated; three preoculars; a narrow elongate subocular, as long as orbit; two or three postoculars; ten supralabials, first small, triangular, narrowly in contact with rostral; second high, reaching almost to canthus rostralis; third much the largest, broadly in contact with subocular; fourth and fifth scales separated from subocular, each by a single scale; temporal scales distinctly enlarged, larger than, or as large as, posterior labials; mental broadly triangular, wider than rostral; eleven lower labials, first, seventh, and eighth largest; a pair of large chin shields, much longer than wide, broadly in contact, bordered by three labials; 5 pairs of scales between chin shields and first ventral; 28 scales from angles of mouth across occiput; 13 scales between supraoculars; 29 scale rows on neck (at seventh ventral) ; 21 on body; ventrals, 175; 56 subcaudals; anal single; temporal scales perfectly smooth, body scales slightly keeled on the eight or ten median rows. Head rather angular, flattened above and depressed in supraocular region. Tail prehensile.

Color in life.-Above bright yellow with a darker yellow lateral streak; tail with a few small reddish brown spots near tip (in alcohol entire snake almost paper white with practically no trace of marking).

Measurements of type and cotype of Trimeresurus mcgregori sp. nov.

$\begin{array}{lcc} & \text { Type. } & \text { Cotype. } \\ \text { Total length } & 865 & 702 \\ \text { Tail } & 120 & 100 \\ \text { Head width } & 25 & 25 \\ \text { Head length } & 36 & 33 \\ \text { Eye to end of snout } & 12 & 92 \\ \text { Eye to mouth } & 6 & 5 \\ \text { Supraocular width } & 16 & 14 \\ \text { Length of eye } & 4.5 & 4 \\ \text { Width of eye } & 3.2 & 2.8\end{array}$

Variation.-A second specimen from the same locality shows a certain amount of variation. The scale counts are as follows: Ventrals, 179; subcaudals, 59; scale rows on neck (at seventh ventral), 29; body, 21 rows; scales between eyes, 13; upper labials, 11-10; lower labials, 12; three scales behind supranasals bordering the rostral. On the right side the third labial does not touch the subocular; the lateral stripe covers one whole and a half scale rows.

Remarks.-This species belongs to the $T$. gramineus Shaw group, which includes $T$. flavomaculatus and $T$. halieus, of the 162323-8 
Philippines. It is differentiated from that group, however, ${ }^{1}$ by the striking color with no dark markings, a larger number of scales on snout and supraocular region, and larger unkeeled temporals; the supranasals are larger and more clearly differentiated. Mr. McGregor, its discoverer and for whom I take pleasure in naming it, states that it is not rare on Batan Island. In a memorandum dated June 12, 1907, he says:

Our party went to the summit of the mountain. On the return a large yellow snake was found resting at about 2 meters from the ground coiled on some leaves that had lodged among the thick stems of a kind of large grass.

The snake was struck with an alpen-stock and fell to the ground. In attempting to put a string on its neck I was scratched by the fangs, between the last two joints of my thumb. Mr. H. G. Ferguson immediately made several cuts across the wound with a pocket knife and tied a string around the thumb. My hand and forearm were swollen by evening. The swelling subsided within a couple of days. There was very little pain, and no further trouble was experienced.

\section{LIZARDS}

Hemidactylus luzonensis Taylor. Plate I, fig. 2, $b$ and $c$.

Hemidactylus luzonensis TAYLOR, Philip. Journ. Sci., Sec. D (1915), $10,93$.

This species was first described from a single mutilated female specimen. I have since examined several other specimens of this rare lizard. Four were presented to me by Dr. Edward S. Ruth, of the University of the Philippines. Several other specimens have been collected for the Bureau of Science collection.

Description of species.-(Adult male, No. 1620, E. H. Taylor collection; collected at Manila in 1916, by Edward S. Ruth.) Head flattened; snout rather oviform, more than twice as wide as deep, elongate, little less than twice the diameter of eye, one and one-half times the distance of eye from auricular opening; latter distinctly oblique on one side, rather vertical on the other; rostral squarish, upright, with a median notch and a cleft nearly half the depth of the scale; nostril pierced between rostral, first labial, two postnasals, and a supranasal ; supranasals separated by two scales; ten upper labials, the last two very small; nine lower labials; mental triangular followed by two pairs of chin shields, first pair touching one labial and forming a long median suture; second pair in contact with first pair and two labials, but separated from each other by three scales; scales

${ }^{1}$ Compared with Stejneger's description of a Formosan specimen. 
bordering upper and lower labials somewhat enlarged; scales on chin and throat small, those on abdomen imbricate and larger; snout covered with uniform granules, larger than those on occiput or body; occiput with scattered tubercular granules, rather conical; body with about sixteen irregular rows of trihedral tubercles; latter present on limbs; tail but slightly depressed, with whorls of sharply keeled spines marking annulations, about eight spines in transverse rows at base of tail; below enlarged, broadened, imbricate scales; regenerated part of tail without spines; limbs moderate, with digits all clawed, without any trace of webs, the distal phalanx rising from near end of toe; latter long, compressed, much deepened near end; nine divided lamellæ under longest toe, seven under longest finger; a distinct lateral fold from axilla to groin; a short series of femoral pores, five on one side, six on other side.

Color in alcohol.-The specimen is light yellow-brown with no evidence of marking save a dark spot on the snout.

Measurements of Hemidactylus luzonensis Taylor.

\begin{tabular}{lc} 
Total length (tail regenerated) & $\mathrm{mm}$. \\
Width of head & 123 \\
Length of head & 10.5 \\
Snout to vent & 18 \\
Foreleg & 58 \\
Hind leg & 22.5 \\
\hline
\end{tabular}

Variation.-The variation noted among specimens is largely in the markings. The live specimens examined usually exhibited a series of large dim dark blotches on the back, alternating with lighter markings. In most specimens the spiny tubercles on the back were white (see Plate I, fig. $2, b$ and $c$ ). The skin above the auricular opening forms an indistinct flap or fold (scarcely noticeable in preserved specimens), which is usually held distended in living or freshly killed specimens; this character is very evident and is shown in Plate I, fig. $2, b$ and $c$. The fold of skin on sides of body is prominent in living specimens and is shown clearly in the figure mentioned.

Remarks.-Evidently a rare form; most closely allied to $H$. depressus but easily distinguished by the longer snout, the character of the tail and the preanal pores, and the absence of webs on the feet. Known only from the Philippines.

Lepidodactylus naujanensis sp. nov.

Type-No. 2006, E. H. Taylor collection; collected April 25, 1916, at Naujan Lake, Mindoro, by E. H. Taylor.

Description of type.-Rostral low, more than twice as broad 
as high, not entering nostril; the latter surrounded by first labial and five nasal scales, forming a rounded prominence; postnasal bordering second labial, largest of the five; supranasals separated from each other by two series of three scales, all about the same size as nasal scales; a rather distinct groove on front end of snout; 13-14 upper labials, 13 lower labials; angle of mouth extends scarcely behind posterior vertical of eye; mental scarcely larger than adjacent scales, chin covered with a large number of somewhat enlarged scales, about 35 , which fill all the space in front of a line drawn across jaw between the fifth lower labials, those bordering labials largest; granules on snout larger than those on body; back and sides covered with minute granular scales with scattered, slightly larger, spinelike scales, which are yellow; these also occur on the back part of head and neck; tail rather cylindrical, with a distinct lateral denticulated fringe, the annulations marked by an enlarged spinelike scale in the lateral fringe; scales on upper surface of tail distinctly larger than those on body, those on underside still larger; scales on belly imbricate, much smaller than those under tail; a long series of 25 preanal and femoral pores forming a median sharp angle; pores elongate in shape; limbs well developed, the adpressed hind leg reaches the wrist of the adpressed foreleg; web between toes and fingers very rudimentary; 14 lamellæ under longest toe; toes much wider at end than at base, the basal lamellæ rather scalelike; inner digits on limbs well developed, without claws; eye nearer ear than end of snout; ear slightly nearer eye than foreleg.

Color in life.-Reddish brown above with dim, zigzag, darker marking of brown across back; lighter at base of tail; a dark line between eyes and another on nose; sides dark with minute yellow spots; a more or less distinct row of yellow dots borders belly ventrolaterally; belly canary mixed with brown scales; underside of tail yellow at base, grayish at tip; lower part of eye dark.

Measurements of Lepidodactylus naujanensis sp. nov.

Length

Snout to vent

Snout to foreleg

Tail

Axilla to groin

Foreleg

Hind leg

Width of head

Length of head mm. 
Variation.-Two other adult specimens were taken in the type locality. The following variations are in evidence. One specimen, a female, has 14-13 upper labials; 12 lower labials; the internasal scales are arranged with one large median scute, with a pair of smaller scales on each side; the angle of mouth fails distinctly to reach the posterior vertical of eye; no preanal pores, but a series of 12 enlarged scales on each side, angular medially, representing the pore scales; a series of distinct black spots on each side of tail just above the lateral fringe. The other specimen, also a female, has the internasal scales similar to those of the type save that the second row has 4 instead of 3 scales; upper labials, 13-14; lower labials, 12; calcareous deposits are present on the sides of neck.

On the opposite side of Mindoro, near Sablayan, another adult male specimen was taken. It agrees remarkably well with the type. The row of scales bordering the lower labials are distinctly larger than other chin scales. Preanal pores $12-11$ in broad angular series; the body is gray with bronze-brown, irregular, zigzag markings.

Young.-Six pairs of small eggs were found attached to various trees under bark. These were brought to Manila, and with no special care ten young were hatched. These were very lively, but owing to my inability to obtain suitable food all died soon or were preserved. A male and female emerged from each pair of eggs; they were a uniform grayish brown; the largest measured 32.5 millimeters in length, the smallest, 29 millimeters.

The eggs are smooth, white, flattened on the two sides where they were attached to each other and to the trees. A great many of these eggs were found, but most of them were destroyed in removing them from their resting places.

Remarks.-This species is related to L. christiani Taylor, as shown by the arrangement of the nasals and the separation of the nostril from the rostral. It differs, however, in the development of the web between the toes; there is no skin fold on the femur, and the tail is essentially different.

The type and cotype, from Naujan Lake, Mindoro, were found under leaves of small climbing vines on trees. Other specimens observed escaped. The habitat is especially similar to that of the small Siaphos kempi, described from the same locality. On two occasions the two species were observed on the same tree. This species is probably common in the type locality.

Gekko mindorensis sp. nov. Fig. 2.

Type.-No. 499, E. H. Taylor collection; collected at Pocanil Point, Mindoro, May 4, 1916, by E. H. Taylor. 
Description of type.-Head moderately large, rather oviform; distance from eye to snout somewhat longer than distance from eye to auricular opening; latter at least one-half diameter of eye, oval, distinctly oblique; rostral large, wider than deep, with a suture above, medially; nostril large, obliquely oval, surrounded by rostral, first labial, two subequal supranasals, and a postnasal; rostral forming the longest side of nostril; a single scale inserted between the two anterior supranasals; twelve upper labials; ten lower labials; the line of mouth makes
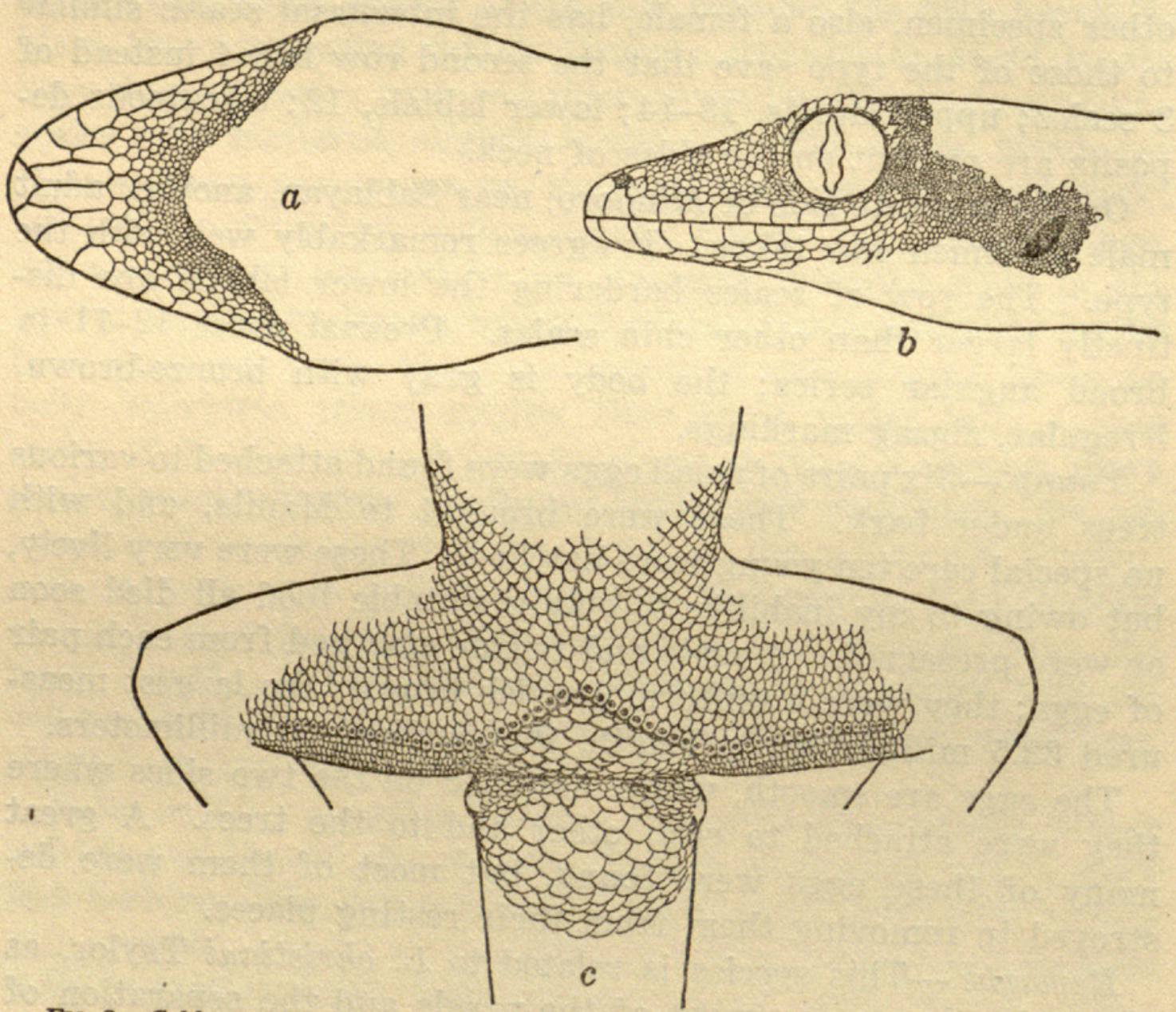

FiG. 2. Gekko mindorensis sp. nov., $\times 2$. $a$, chin; $b$, head, side view; $c$, anal region.

a sharp angle upward immediately below eye; loreal regions covered with rather enlarged granules, largest immediately in front of eye; a row of enlarged granules bordering upper labials above; interorbital region and medial area on snout depressed, covered with much smaller granular scales; occipital region covered with minute granules interpersed with indistinct larger granules; mental triangular, followed by two elongate chin shields nearly three times as long as wide; a few enlarged pentagonal scales behind and at sides of chin shields; throat covered with equal-sized granules, larger than those on dorsal surface. Body rather slender, covered above with minute gran- 
ules, intermixed with numerous rounding granules; an indistinct lateral fold; about 30 longitudinal rows of scales between the folds; preanal and femoral pores continuous, 27-28 on each side, slightly separated medially, a total of 55 pores. Tail regenerated wholly; above covered with fine granules, with no trace of annulations, below with irregular large broad scales; two enlarged tubercles at base of tail. Extremities moderate; toes not greatly dilated, about 16 lamellæ under longest toe; no rudiment of web evident.

Color in life.-Above almost uniform olive brown with but very little variation delineating the lighter and darker areas. No markings evident; below yellowish white.

$$
\text { Measurments of Gekko mindorensis sp. nov. }
$$

Total length

Tail, regenerated

Snout to foreleg

Snout to vent

Snout to ear opening

Foreleg

Hind leg

$\mathrm{mm}$.

162

80

34.5

82

22

30

40

Variation.-Eight other specimens have been studied, taken by myself about Naujan Lake, Mindoro. These specimens are all young; they are darker than the type, with blackish stripes across the backs and on the tails. Two males in the lot have 62 and 64 pores, respectively.

Remarks.-This species is related to Gekko monarchus, from which it differs as shown in the table of measurements. Several specimens of that species are at hand for comparison.

Comparative measurements of Gekko mindorensis and G. monarchus.

G. mindorensis.

$\begin{array}{cr}82 & 85 \\ 26 & 29 \\ 35 & 40 \\ 16 & 18 \\ 18 & 20 \\ 6.5 & 5 \\ 3.3 & 2 \\ 6.75 & 8 \\ 54 & 33 \\ 30 & 45\end{array}$

Two males of equal size are compared. The ear-opening of

Snout to vent $(\mathrm{mm}$.

Foreleg (mm.)

Hind leg ( $\mathrm{mm}$.

Width of body (mm.)

Width of head (mm.)

Diameter of eye (mm.)

Diameter of auricular opening ( $\mathrm{mm}$.)

Interorbital measurement ( $\mathrm{mm}$.)

Preanal and femoral pores

Scale rows across belly

G. monarchus.

G. mindorensis is larger, equaling half the eye. The eye itself is much larger than that of G. monarchus; the interorbital distance is less; there is a much larger number of preanal and 
femoral pores, the number of scale rows across the belly is about fifteen less; the tubercles are fewer and much less prominent and the very characteristic markings of $G$. monarchus are wanting.

The type specimen was captured with the assistance of $\mathrm{Mr}$. Clark Burks, of Sumagui, Mindoro; two eggs were found at the same time.

Oshima $^{2}$ has described Gekko kikuchii from Botel Tobago, Formosa, which seems to vary from Gekko monarchus in much the same way as does the present species. Although no specimens of the species are at hand for comparison the following differences are evident: Gekko mindorensis has many more femoral pores, 55 to 64 , while 48 are recorded in G. kikuchii; the limbs are longer in the present species, and the basal web is wanting on the feet in both sexes.

Siaphos kempi sp. nov. Fig. 3.

Type.-No. 2016, E. H. Taylor collection; collected April 23, 1916, at Naujan Lake, Mindoro, by E. H. Taylor.

Description of type.-Head short, snout blunt, not especially depressed; rostral covering tip of snout, the part visible above much less than the depth of snout at the posterior border of rostral; no supranasals; frontonasal large, the suture with rostral equal to, or smaller than, that with nasal, and slightly larger than that with frontal; prefrontals much reduced, separated, not in contact with first supraocular; frontal moderate, about equal to frontoparietal in length, as long as its distance from end of snout, in contact with two supraoculars and first superciliary; frontoparietals fused in a single scale a little broader than long; interparietal triangular, a little wider than frontal, but shorter; parietals forming a suture behind interparietal; four pairs of nuchals ; nasal pierced medially by nostril, touching a single labial; two frenals, both higher than wide; four supraoculars, last longest, second widest; eight superciliaries; several much enlarged temporals; seven upper labials, fifth below center of eye; five or six lower labials; mental larger than rostral; ear opening obliquely oval, moderately large; eye nearer tip of snout than ear opening; limbs small, barely touching when adpressed; digits not or but slightly compressed; 20 lamellæ under fourth toe; two enlarged preanals; median row of scales under tail slightly widened; 22 scale rows around body; scales smooth, the median dorsal rows widest.

${ }^{2}$ Philip. Journ. Sci., Sec. D (1912) 7, 241. 
Color in life.-Above silvery olive to brown, somewhat lighter on tail; laterally a broad dark stripe from eye to near end of tail, becoming somewhat lighter on tail, bordered above and below with a narrow greenish silver line; head uniform dark brown; belly dirty greenish white with a few small specks of dark color under chin; underpart of tail creamy white; limbs mottled brown and yellowish.

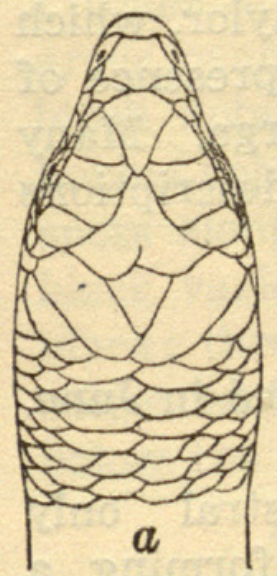

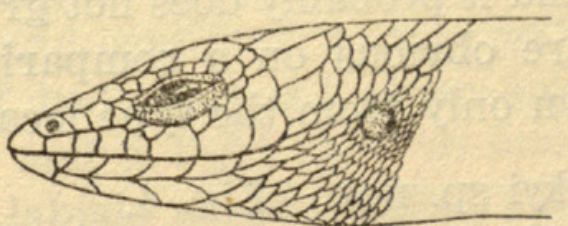

b

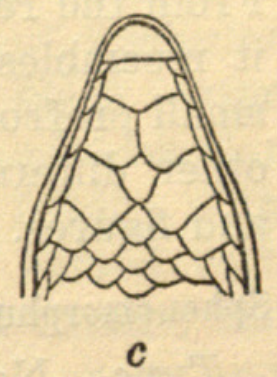

Frg. 3. Siaphos kempi sp. nov., from the type, $\times 4$. $a$, head, dorsal view; $b$, head, lateral view ; $c$, chin.

Measurements of Siaphos kempi sp. nov.

Total length

$\mathrm{mm}$.

93

Tail

53

Axilla to groin

21

Snout to vent

40

Snout to foreleg

14.5

Foreleg

9

Hind leg

14

Variations.-Two other specimens were taken in the same locality; both agree with the type in markings save that both are lighter above; they are practically identical in scalation.

Remarks.-This species appears to be intermediate between Leiolepisma and Siaphos. I have referred it to the latter rather than to the former genus because of its closer superficial resemblance to the other Philippine members of that genus and the fewer prefrontals and shorter limbs; the ear opening, however, is large and distinct. The known Philippine species of Leiolepisma have the divided frontoparietal; the three known species of Siaphos have the frontoparietal single.

The species is named for Ollie C. Kemp, Mangyan agent in Mindoro, who accompanied me on the collecting trip to Naujan Lake and assisted in making collections.

The species was found living under the leaves of small, closeclinging vines on trees. When these vines were loosened at the base of the tree and torn down, the lizards were revealed on the 
sides of the trees at some distance from the ground and they immediately took refuge much higher up the tree; thus many specimens escaped. Only three specimens, brought down with the vines, were captured.

This species differs markedly from the two small species Siaphos infralineolatum Peters and Siaphos quadrivitatum Peters in size, markings, and the presence of an auricular opening. From the recently described Siaphos auriculatum Taylor, which it resembles greatly in markings, it differs in the presence of small prefrontals, and it probably does not grow so large. Many other differences are obvious on a comparison of descriptions and figures. Known only from the type locality.

Sphenomorphus lednickyi sp. nov. Fig. 4.

Type.-No. R 1992, E. H. Taylor collection; collected in June, 1917, on Masbate Island, by Victor E. Lednicky.

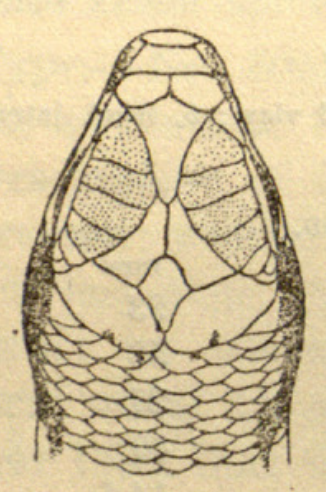

a

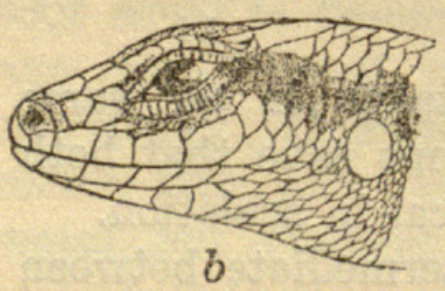

FiG. 4. Sphenomorphus lednickyi sp. nov., No. 291, E. H. T. collection, $\times 3$. $a$, head, dorsal view; $b$, head, lateral view.

Description of type.-Rostral only slightly visible from above, forming a broad, rather curved suture with frontonasal; latter much broader than deep, broader behind than in front, in contact with anterior frenal; prefrontals large, broadly in contact, touching both frenals laterally, not in contact with first supraocular; frontal as wide as, or slightly less than, the supraocular region, in contact with first superciliary and two supraoculars, narrowed behind; frontoparietals distinct, rather elongate, broadly in contact; interparietal much longer than wide, with a distinct eyespot; parietals forming a suture behind interparietals; no nuchals present; five supraoculars, last very small, first deepest, second widest; nostril pierced in a single nasal; no supranasals; anterior frenal not as high as nasal, much higher than wide; second frenal wider at top than bottom, lower than anterior; three preoculars superimposed, between first superciliary and third labial; six upper labials, fourth and fifth under eye, but separated from orbit by several scales; third labial smaller than second; five lower labials; mental small, followed by a very wide postmental; three pairs of chin shields, only first pair in contact; four enlarged temporals, that bordering parietal largest; auricular opening very large; tympanum very superficial; 40 rows 
of scales around belly; scales on sides in longitudinal rows, all rows subequal in size; preanal scales distinctly enlarged; limbs well developed, the adpressed hind leg reaching wrist of foreleg; latter brought forward reaches middle of eye; 22 lamellæ under longest toe; scales below tail scarcely broadened; eye a little nearer end of snout than ear; latter nearer foreleg than end of snout.

Color.-Head and body variegated brown above with dark areas over supraocular region and a median row of irregular black dots, extending somewhat on tail; a heavy black stripe begins behind eye and continues as a broken series of irregular spots along side of body and tail above legs; legs brown, with black variegations and a light spot on knee; toes barred with black; throat and labials muddy white; belly light cream; tail below with dark flecks; a few cream yellow spots above and below the black stripe on neck.

\begin{tabular}{lcc}
\multicolumn{3}{c}{ Measurements of Sphenomorphus lednickyi sp. nov. } \\
& Type. & Cotype. \\
& $\mathrm{mm}$. & $\mathrm{mm}$. \\
Total length & 106 & 114 \\
Snout to vent & 46 & 50 \\
Snout to foreleg & 18 & 18.5 \\
Tail & 60 & 64 \\
Axilla to groin & 27 & 28 \\
Width of head & 7 & 8 \\
Length of head & 8.6 & 8.5 \\
Foreleg & 15 & 14 \\
Hind leg & 21 & 22.5
\end{tabular}

Variation.-A second specimen from the same locality agrees in scalation, but the head is broader, and the broad black stripe is almost wanting along the body. The regenerated tail has broad scales above and below.

Remarks.-The two specimens were collected in Masbate, near the Aroroy gold mines, by Mr. Victor E. Lednicky. He states that they appear to be plentiful in that locality. Superficially this species resembles Sphenomorphus curtirostris, but the latter has the frontoparietal single, fourteen lamellæ under longest toe, more upper labials, and the nasal followed by superimposed frenals. It is a larger species. I take pleasure in naming the species for its discoverer.

Sphenomorphus llanosi sp. nov. Plate II.

Type.-Santo Tomas Museum, Manila, specimen unnumbered, collector unknown. Probably from Luzon.

Description of type.-Habit lacertiform; snout narrower and 
longer than in Sphenomorphus jagori; rostral much wider than high, much narrowed laterally in front of first labial below nasal; frontonasal little broader than deep, forming a straight suture with rostral, laterally in contact with upper anterior frenal, posteriorly in contact with frontal; prefrontals rectangular, separated in the middle, in contact laterally with upper anterior and posterior frenals, and a single superciliary; frontal much elongate, narrowed behind and in front; distance between supraocular regions about one-third the width of the region above one eye; frontal little shorter than frontoparietal and interparietal length, in contact with two supraoculars; frontoparietals slender, pointed in front, forming a common suture much more than half their length; interparietal nearly as broad as frontal, but not nearly as long, as large as frontoparietals; parietals large, in contact behind interparietals, touching last supraocular and two small postoculars; no nuchals; nasal quite large, the scale placed diagonally, touching only one labial; two anterior frenals superimposed, the two not as high as nasal, but higher than the very large frenal following, which is much wider at top than bottom, touching two labials; two preaculars, the lower largest, followed by two moderately large scales below eye, the second partly wedged between fifth and sixth labials; ten superciliaries; five large supraoculars followed by two paired scales, the first supraocular more than a third of the length of the supraocular region, second widest; nine upper labials, sixth below orbit, sixth and seventh largest; five distinctly enlarged temporals, the largest bordering parietal; eight or nine lower labials ; one unpaired postmental; two paired chin shields, first pair in contact, second separated by one scale; anals enlarged; 23 lamellæ under longest toe; ear opening moderate, vertically oval; 42 scale rows around middle of body. Adpressed hind leg reaches beyond elbow of adpressed foreleg; adpressed foreleg reaches anterior corner of eye.

Color in alcohol.-Above rich, reddish brown traversed by about thirteen indistinct bands of light, black-edged dots on back, and continuing on tail; behind eye to above foreleg is a large, broad, dark brown stripe bordered below by a white stripe, which begins on second labial and continues back to ear, then widens and takes a backward and downward course to foreleg; below this there is a rather irregular mottled area of brown; lower labial flecked with brown; limbs above mottled with elongate light spots; sides somewhat lighter, flecked with brown; a brown 
area above hind limb; below yellowish; there is a very dim row of brown spots along upper lateral region.

Measurements of Sphenomorphus llanosi sp. nov.

Total length

Tail (end regenerated)

Foreleg

Hind leg

Axilla to groin

Snout to foreleg

Snout to eye

Eye to ear

Ear to foreleg

Width of head

$\mathrm{mm}$.
148
60
16
26
27.5
21.5
5
5.2
8.5
9

$\mathrm{mm}$.

60

16

27.5

21.5

5.2

9

Remarks.-Closely related to S. jagori, but differs in the following points: The first frenal is divided and the scales superimposed; the second frenal is proportionally much larger; there are five instead of four large supraoculars; the frontoparietals are slenderer and extend farther forward; the coloration is also distinctive; there are more rows of scales about the body.

Unfortunately the collections in the Santo Tomas Museum are unnumbered, and for the most part are without authentic localities. It is highly probable that this species is from Luzon, and perhaps the northern part of the island. Only a single specimen, the type, is present in the collection. I take pleasure in naming this species in honor of Father Florencio Llanos, director of the University of Santo Tomas, who has generously permitted me to study the collections in the museum of the university and to describe the new species. 


\section{ILUSTRATIONS}

\section{Plate I}

Frg. 1. Typhlops longicauda sp. nov., from the type, $\times 5$. $a$, lateral view; $b$, dorsal view; $c$, ventral view.

2. $a$, Hemidactylus frenatus Duméril and Bibron; $b$ and $c, H e m i-$ dactylus luzonensis Taylor.

\section{Plate II}

Sphenomorphus llanosi sp. nov., from the type, about $\times 1.5$.

\section{TEXT FIGURES}

Fig. 1. Trimeresurus mcgregori sp. nov., from the type, $\times 1$. a, head, lateral view; $b$, head, dorsal view; $c$, chin.

2. Gekko mindorensis sp. nov., $\times 2$, $a$, chin; $b$, head, lateral view; $c$, anal region.

3. Siaphos kempi sp. nov., from the type, $\times 4$. $a$, head, dorsal view; $b$, head, lateral view; $c$, chin.

4. Sphenomorphus lednickyi sp. nov., $\times 3$. $a$, head, dorsal view; $b$, head, lateral view. 


$$
\text { J } 5 x^{4}
$$




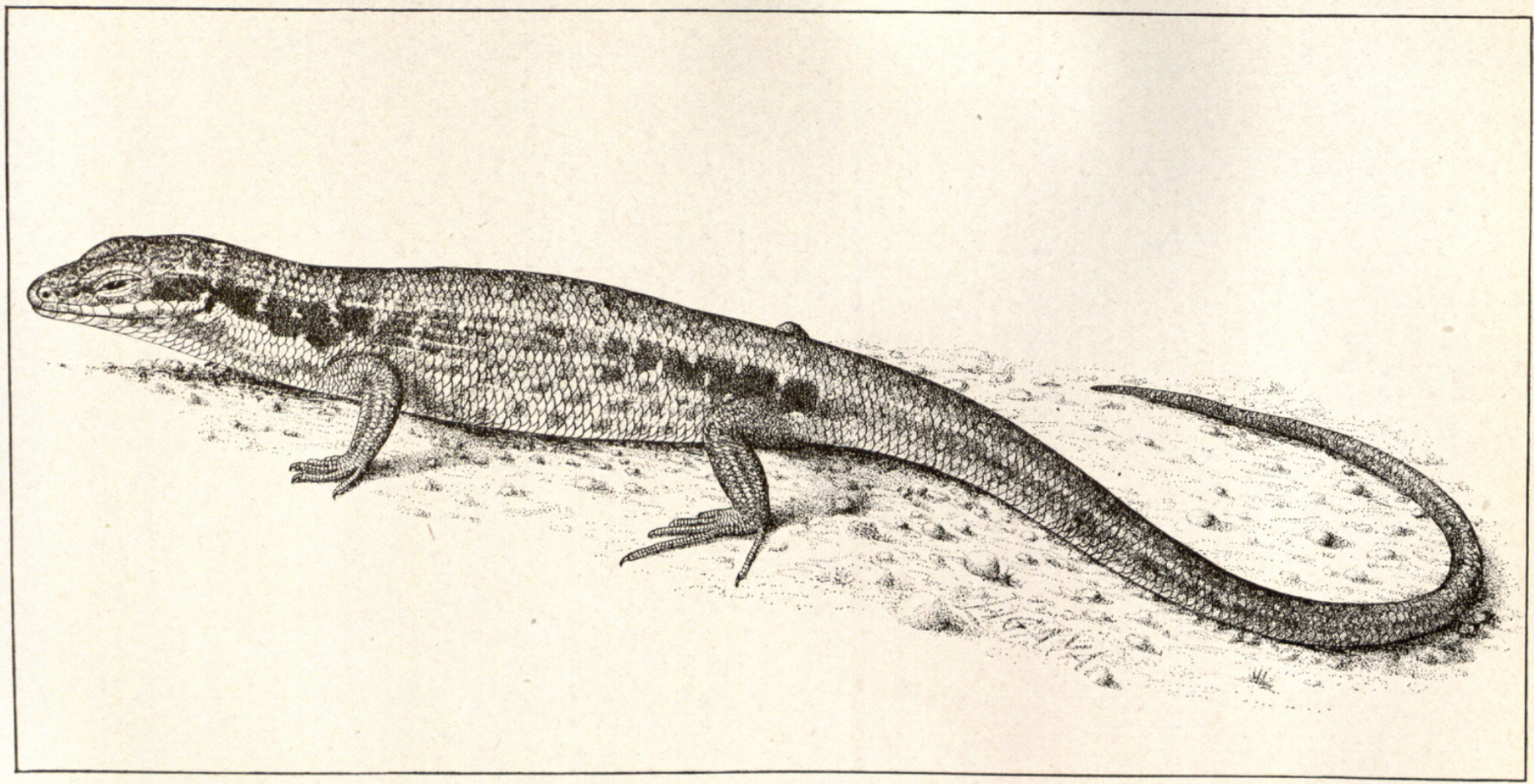

PLATE II. SPHENOMORPHUS LLANOSI SP. NOV., FROM THE TYPE, ABOUT $\times 1.5$. 


\section{$2 \mathrm{BHL}$ Biodiversity Heritage Library}

Turner, Edward H. 1919. "New or rare Philippine reptiles." The Philippine journal of science 14, 105-125. https://doi.org/10.5962/bhl.part.14566.

View This Item Online: https://www.biodiversitylibrary.org/item/1124

DOI: https://doi.org/10.5962/bhl.part.14566

Permalink: https://www.biodiversitylibrary.org/partpdf/14566

\section{Holding Institution}

Missouri Botanical Garden, Peter H. Raven Library

\section{Sponsored by}

Missouri Botanical Garden

\section{Copyright \& Reuse}

Copyright Status: Public domain. The BHL considers that this work is no longer under copyright protection.

This document was created from content at the Biodiversity Heritage Library, the world's largest open access digital library for biodiversity literature and archives. Visit BHL at https://www.biodiversitylibrary.org. 